\title{
TOEPASSING VAN STEEKPROEVEN BIJ DE ACCOUNTANTSCONTROLE
}

\author{
door R. de Koning
}

Aan het onderwerp "steekproeven bij de accountantscontrole" werden enkele jaren geleden in dit blad verschillende artikelen gewijd. Hierin werd in het bijzonder aandacht besteed aan een wiskundige benadering van dit vraagstuk.

In het hiernavolgende wil ik op enige praktische problemen, welke met het toepassen van een wiskundige steekproef bij de accountantscontrole samenhangen nader ingaan. Ik zal mij hierbij beperken tot de problemen welke rijzen bij de controlewerkzaamheden welke de accountant moet verrichten om tot een oordeel omtrent de juistheid van een jaarrekening te komen.

\section{Probleemstelling}

Controle of een bepaalde massa aan de daaraan gestelde eisen voldoet, is in vele gevallen alleen mogelijk door de elementen, waaruit de massa is opgebouwd afzonderlijk te controleren.

Controleert men alle elementen dan verkrijgt men omtrent het al dan niet voldoen van de massa aan bovenbedoelde eisen volledige zekerheid. Beperkt men zich tot een steekproef dan loopt men het risico dat een aantal elementen dat niet aan de eisen voldoet (,fouten”) onontdekt blijft.

Tussen de omvang van de massa, de omvang van de steekproef, de grootte van bovenbedoeld risico en het aantal onontdekte fouten bestaat een verband dat in een wiskundige formule kan worden weergegeven.

De accountant wordt bij de controle van een jaarrekening veelvuldig geconfronteerd met massa's als hierboven bedoeld. De hiervoor benodigde tijd is - als alle elementen worden gecontroleerd - hoog in verhouding tot de tijd welke in totaal benodigd is om tot een oordeel te komen.

De vraag welke thans aan de orde is, is in hoeverre de accountant controle van alle elementen kan vervangen door een steekproef, waarvan de omvang met behulp van bovenbedoelde wiskundige formule wordt vastgesteld.

Hierbij doen zich de volgende bijzondere problemen voor welke voortvloeien uit de aard van de accountantscontrole:

1. Het is niet mogelijk een volkomen objectieve definitie van het begrip „fout" te geven.

2. De jaarrekening is niet uitsluitend opgebouwd uit massa's als hierboven bedoeld.

3. Vele van de getallen, waaruit de jaarrekening is opgebouwd zijn min of meer onnauwkeurig. Deze onnauwkeurigheid manifesteert zich met name bij de waarderingsproblemen, waar de accountant bij zijn oordeelsvorming mee te maken krijgt.

4. De elementen waaruit een administratieve massa is opgebouwd zijn veelal „posten" van uiteenlopende bedragen. Bij de beoordeling van de betekenis van een eventuele fout zal in vele gevallen mede rekening moeten worden gehouden met het bedrag van de foutieve post.

5. Voor zover het al mogelijk is met betrekking tot administratieve massa's een normale foutenfrequentie (met een bepaald gemiddelde en een bepaalde sprei- 
ding) vast te stellen heeft deze slechts betrekking op een gedeelte van de fouten, namelijk de toevallige.

\section{Fouten}

In dit artikel zullen onder ,fouten" worden verstaan alle posten welke een plus aan controlewerkzaamheden vereisen boven die welke zijn voorzien in de algemene instructie en het controleprogramma. Over het algemeen zijn dit de posten welke aanleiding geven tot het maken van een ,,aantekening" in het controledossier. Al deze posten zijn voor de oordeelsvorming van de accountant van belang, ook al zijn het lang niet altijd fouten in de betekenis van ,onjuiste posten”. Over wat juist of onjuist is, is trouwens bij de accountantscontrole veelal verschil van opvatting mogelijk.

$\mathrm{Bij}$ de afwerking van een aantekening wordt de betekenis er van voor de oordeelsvorming van de accountant nader vastgesteld. Hierbij moet gedacht worden aan het oordeel omtrent de juistheid van de jaarrekening. Het oordeel omtrent de gecontroleerde massa (als samenstellend bestanddeel van de jaarrekening) is hierin dan begrepen.

Het is mogelijk dat de accountant pas tot een oordeel omtrent de betekenis van een ,fout" kan komen nadat hij heeft nagegaan of andere soortgelijke posten uit de massa tot een soortgelijke aantekening aanleiding geven. Bij een volledig onderzoek van de massa zullen deze posten in elk geval in het onderzoek worden betrokken. Bij een steekproef echter zal hiertoe een gericht onderzoek noodzakelijk zijn, waarbij de betreffende posten op grond van de kenmerken van de aangetroffen „foutpost" uit de massa worden geselecteerd. Dit gericht onderzoek reken ik ook tot het afwerken van de oorspronkelijke aantekening. Overigens zijn de werkzaamheden te verrichten bij het af werken van aantekeningen niet afhankelijk van de vraag of de aantekening bij een steekproef of bij een volledige controle werd gemaakt.

Aantekeningen welke betrekking hebben op een nieuwe ontwikkeling in de activiteiten van de gecontroleerde, op bescheiden welke niet op de normale plaats zijn opgeborgen, op de doelmatigheid van de verslaglegging, op de interpretatie van voorschriften, op de organisatie van de interne controle zijn voorbeelden van fouten waarvan de betekenis voor het accountantsoordeel kan worden vastgesteld. Bij een steekproef gemaakt, geven dergelijke aantekeningen geen aanleiding de steekproef uit te breiden. Het is echter ook mogelijk dat de „fout” onverklaarbaar is en dus niet afgewerkt kan worden. In dit geval wordt - voorshands - aangenomen, dat de fout toevallig is gemaakt. De steekproefomvang wordt dan vergroot op de wijze als in onderdeel III nader zal worden uiteengezet. Het is uiteraard mogelijk dat bij de voortgezette controle blijkt, dat de fout alsnog kan worden verklaard.

\section{Vaststelling van de steekproefomvang}

In de in onderdeel I bedoelde formule komen de volgende grootheden voor:

a. De steekproefomvang

b. Het aantal fouten in de steekproef

c. Het aantal fouten in de gehele massa

d. De omvang van de massa

e. De kans dat de uit de steekproef getrokken conclusie onjuist is. 
Bij de accountantscontrole gaat het als regel in eerste instantie om de omvang van de steekproef. Voor de berekening hiervan zullen dus groorheden $b \mathrm{t} / \mathrm{m} \mathrm{e}$ bekend moeten zijn. Omtrent elk van deze grootheden valt het volgende op te merken:

\section{Ad b. Het aantal fouten in de steekproef}

Omtrent het aantal fouten dat men in een steekproef zal aantreffen is uiteraard van te voren niets bekend. Dit is echter geen bezwaar. Wij beginnen namelijk dit aantal op nul te stellen en bepalen op basis hiervan en van de eveneens bekende grootheden $\mathrm{ct} / \mathrm{m}$ e een bepaalde steekproefomvang. Vinden wij bij toepassing van deze steekproef geen enkele als toevallig aan te merken fout, dan was onze veronderstelling - nul fouten in de steekproef - juist. Stuiten wij op één toevallige fout dan berekenen wij een nieuwe steekproefomvang, nu op basis van een wairde één voor het aantal fouten in de steekproef. Deze omvang zal groter zijn dan de aanvankelijke. Wij breiden nu de steekproef uit tot de nieuwe omvang is bereikt. Worden geen verdere toevallige fouten aangetroffen dan is deze steekprocfomvang de juiste. Stuiten wij op cen tweede toevallige fout dan substitueren wij in de formule voor het aantal fouten in de steekproef de waarde twee. Wij vinden dan een daarbij behorende wederom grotere steekproefomvang, waartoe wij de steekproef nu weer verder uitbreiden. Op deze wijze gaan wij door tot de juiste steckproefomvang is gevonden. Hierbij kan blijken dat het aantal posten dat moet worden gecontroleerd gelijk wordt aan de omvang van de massa. Dit betekent dat tot volledige controle moet worden overgegaan. Is de steekproef voltooid dan gelden alle aangetroffen toevallige fouten als , afgewerkt”.

\section{Ad c. Het aantal fouten in de gebele massa}

Het werkelijk aantal fouten dat de massa bevat is - evenmin als het aantal fouten in de steekproef - van te voren bekend. Ook achteraf blijkt dit aantal niet, tenzij op grond van het aantal in de steekproef aangetroffen toevallige fouten tot volledige controle moest worden overgegaan. .

Het gaat evenwel niet om het werkelijk aantal fouten dat de massa bevat, maar om het maximaal toelaatbaar geachte aantal. Wij gaan daarom uit van de veronderstelling dat het aantal fouten in de massa dit maximum niet overschrijdt en bepalen op basis hiervan - als ook de andere grootheden in de formule gegeven zijn de omvang van de steekproef.

Als gevolg van bovenomschreven werkwijze geeft de conclusie welke wij uit het steekproefresultaat trekken alleen de meest ongunstige mogelijkheid aan. De massa kan na voltooiing van de steekproef nog een aantal onontdekte fouten bevatten van maximaal het toelaatbaar geachte aantal dat bij de berekening van de steekproefomvang in aanmerking is genomen. Het werkelijke aantal onontdekte fouten kan belangrijk lager liggen dat dit maximum, maar dit is bij de gegeven steekproefomvang niet vast te stellen. Evenmin is iets bekend omtrent de aard van de onontdekte fouten (af te werken fouten of onverklaarbare fouten).

Het is echter denkbaar dat de accountant met behulp van de andere controlemiddelen welke hem ter beschikking staan (zoals onderzoek interne organisatie, verbandcontroles, vergelijking met begrotingen, cijferbeoordelingen) toch een voldoende beeld van de betekenis van eventuele fouten, welke bij de steekproef niet zijn ontdekt, kan verkrijgen. 
Het gaat hierbij om de betekenis voor zijn oordeel omtrent de juistheid van een jaarrekening. Bij deze oordeelsvorming zal de accountant mede rekening moeten houden met de marges welke bij de - naast de steekproef - verrichte overige controlewerkzaamheden moeten worden aanvaard. Voorts zal hij er zich rekenschap van moeten geven, dat de jaarrekening is opgebouwd uit min of meer onnauwkeurige getallen (waarderingsproblemen). Het is in beginsel mogelijk de gezamenlijke betekenis van al deze factoren te kwantificeren. Langs deze weg zal de accountant die bij zijn controlewerkzaamheden voor een bepaalde massa toepassing van een steekproef overweegt tot een vaststelling van het maximaal toelaatbare aantal onontdekte fouten kunnen komen.

Wordt bij de controle van één jaarrekening meer dan één massa aan een steekproef onderworpen, dan zal de accountant rekening moeten houden met de gezamenlijke betekenis van eventueel bij de steekproeven onontdekt gebleven fouten voor zijn oordeelsvorming. Van meer dan één massa is ook sprake als een massa wordt gesplitst, bv. naar de grootte van de posten of in een aantal perioden welke binnen hetzelfde boekjaar vallen.

\section{Ad d. De omvang van de massa}

De vaststelling van de omvang van de massa levert als regel weinig moeilijkheden op. Exact behoeft deze vaststelling niet te zijn omdat niet te grote verschillen praktisch geen invloed hebben op de omvang van de steekproef.

In de praktijk kan de omvang van de massa veelal worden vastgesteld tegelijk met de selectie van de in de steekproef op te nemen elementen. Men gaat dan in eerste instantie uit van een geschatte omvang van de massa. Blijkt deze in belangrijke mate van de werkelijkheid af te wijken dan wordt de steekproefomvang aangepast.

\section{Ad e. De kans op een onjuiste conclusie}

Het toepassen van een steekproef in plaats van volledige detailcontrole houdt de kans op een onjuiste conclusie in. Voor de vaststelling van de steekproefomvang zal deze kans bekend moeten zijn. Hiervoor bestaat echter bij de accountantscontrole geen norm. De accountant die een steekproef wil toepassen zal met betrekking tot het bepalen van deze norm dus subjectief te werk moeten gaan. Wenst hij de kans op een onjuiste conclusie op nul te stellen, m.a.w. 100\% zekerheid, dan is er geen ruimte voor het toepassen van een steekproef. Een geringe daling beneden deze 100\% kan echter reeds een belangrijke daling van het aantal te controleren posten met zich brengen.

Van de tegen het toepassen van steekproeven bij de accountantscontrole in te brengen bezwaren is het ontbreken van een norm voor de te aanvaarden kans op een onjuiste conclusie naar mijn mening de belangrijkste.

$\mathrm{Er}$ is wel op gewezen dat ook andere controlemiddelen (waaronder volledige detailcontrole) geen $100 \%$ zekerheid bieden. Dit is inderdaad een argument voor het toepassen van een steekproef, maar het helpt ons niet aan een norm voor de betrouwbaarheid (lager dan 100\%) welke hierbij geëist moet worden. De betrouwbaarheid van de andere controlemiddelen is namelijk niet meetbaar, zodat deze niet met de - wel meetbare - betrouwbaarheid van de steekproef vergeleken kan worden. 


\section{De betekenis van het bedrag der te controleren posten}

Aan de vaststelling van het toelaatbare aantal fouten gaat de vaststelling van een toelaatbaar foutbedrag vooraf. Dit bedrag moet worden omgezet in een aantal fouten. Hiervoor bestaan twee methoden:

\section{De stratificatiemethode}

$\mathrm{Bij}$ de stratificatiemethode worden de posten waaruit de massa is samengesteld naar de grootte van de bedragen in een aantal klassen ingedeeld. Voor alle posten in één klasse wordt het gemiddelde van de klassegrenzen als bedrag aangenomen. Dit gemiddelde wordt gedeeld op het toelaatbare foutbedrag. Het quotiënt geeft het voor die klasse toelaatbare aantal fouten aan. Op basis hiervan berekent men de steekproefomvang voor deze klasse.

Deze methode leidt dus tot een afzonderlijke steekproef voor elke klasse. Hiermede moet rekening gehouden worden bij het vaststellen van een betrouwbaarheidsnorm voor elk van deze steekproeven. De conclusies welke uit de afzonderlijke steekproefresultaten worden getrokken bevatten namelijk elk een kans dat zij onjuist zijn. Voor de massa als geheel is deze kans groter dan voor de afzonderlijke deelmassa's. Als uitgegaan wordt van een bepaalde betrouwbaarheidsnorm voor de conclusie ten opzichte van de massa als geheel zal deze norm voor de afzonderlijke deelmassa's dus hoger gesteld moeten worden

\section{De guldenrangnummermethode}

De guldenrangnummermethode werd in het nummer van december 1961 van dit blad door collega Van Heerden geïntroduceerd. Bij deze methode wordt de massa beschouwd als een verzameling van posten, welke elk $f 1,-$ groot zijn. Het in guldens uitgedrukte toelaatbare foutbedrag is dan tegelijk het aantal toelaatbare fouten. De steekproefomvang geeft een aantal te controleren guldens aan.

$\mathrm{Bij}$ de controle zullen deze guldens blijken deel uit te maken van posten bestaande uit meerdere guldens. Deze worden dan in dezelfde controlehandeling meegecontroleerd. Anderzijds zal deze methode er toe kunnen leiden dat in één post twee of meer malen een gulden moet worden gecontroleerd. Dit geschiedt dan dus ook in één controlehandeling.

Een kleine variatie op de guldenrangnummermethode verkrijgt men als men de massa opgebouwd denkt uit posten van bv. telkens $f 10,-, f 100,-$ enz.

De guldenrangnummermethode biedt verschillende voordelen boven de stratificatiemethode. Men vermijdt de werkzaamheden verbonden aan het indelen van de posten in klassen en de hierbovengenoemde complicatie met betrekking tot de betrouwbaarheid treedt niet op. Voorts zal de vaststelling van de omvang van de massa (de telling) veelal tegelijk met het selecteren van de in de steekproef op te nemen guldens kunnen plaats vinden. De betekenis van dit laatste voordeel wordt echter beperkt doordat ten behoeve van de selectie een groot aantal tussentotalen moet worden bepaald.

\section{De selectie van de in de steekproef op te nemen elementen}

Bij de selectie van de in de steekproef op te nemen elementen (posten, guldens) zal men er zorg voor moeten dragen, dat elk element een even grote kans heeft om in de steekproef te worden opgenomen. De „blokmethode” voldoet niet aan 
deze eis. Bij deze methode betrekt men in de steekproef een aantal posten, welke behalve het feit dat ze tot één administratieve massa behoren nog een eigenschap gemeen hebben. Door gebruik te maken van tabellen met toevalscijfers kan men aan de gestelde eis (elke post resp. gulden een even grote kans) voldoen.

\section{Slotopmerkingen}

In het voorgaande is bewust geen partij gekozen vóór of tegen toepassing van steekproeven bij de accountantscontrole. Zoals in de aanvang gezegd was de bedoeling van dit artikel alleen enige praktische problemen welke bij deze toepassing rijzen, voor zover het doel van de controle is het geven van een oordeel omtrent de juistheid van een jaarrekening, nader te belichten.

De betekenis van een wiskundige steekproef zie ik voornamelijk daar, waar de accountant op grond van controletechnische overwegingen toch reeds bepaalde onderdelen van de administratie aan een steekproef onderwerpt, maar de omvang hiervan niet langs wiskundige weg vaststelt. De zekerheid welke hij hiermede heeft verkregen zal hij met behulp van de theorie van de wiskundige steekproef kunnen toetsen aan een door hem subjectief te stellen norm.

De vraag welke de controletechnische overwegingen zijn welke de accountant tot het nemen van een steekproef leiden is op zichzelf zeer belangrijk, maar het antwoord hierop ligt buiten het bestek van dit artikel. 